\title{
INNOVATION IN THE AGRI-FOOD SECTOR: EXPLOITING OPPORTUNITIES FOR INDUSTRY 4.0
}

\begin{abstract}
Agri-Food producers have a responsibility to provide safe, secure and sustainable food in a world characterised by disruption and increasing intolerance of waste along supply chains. As such, it is critical that they adopt new technologies to ensure efficient and effective management of their responsibility. While Industry 4.0 (I4.0) technologies can underpin process innovation opportunities, there is a gap in research-based understanding of how they influence innovation practice and outcomes in Agri-Food. In this paper, we investigate how I4.0, as a set of enabling technologies, influences core process innovation practice and product innovation outcomes in Agri-food firms. We present case studies of two Spanish firms processing fresh food products, competing in two important sub-sectors of the industry, meat and fruit \& vegetables. We used secondary material and semistructured interviews as data sources. The findings describe how, in the two cases, I4.0 has enabled responses to new customers requirements through process innovations resulting in enhanced functionality, aesthetics and meaning of the delivered products. Our paper contributes a framework identifying for researchers and managers how I4.0 technologies act as enablers of the core innovation processes and competitive outcomes.
\end{abstract}

Keywords: Industry 4.0, Agri-Food sector, Process innovation, Product innovation.

\section{INTRODUCTION}

Agri-Food (AgF) firms have a responsibility to provide safe, secure and sustainable food. In many countries, traceability is mandatory in order to increase food security for customers, and customer confidence in the safety of their food supply (Costa et al. 2013). The impacts on supply of disruptive events such as climate change, BREXIT and the global pandemic have highlighted the role of enabling innovation capabilities to build resilience, visibility, redundancy, velocity, and flexibility of the food supply chain (Stone and Rahimifard, 2018). Finally, food sustainability is threatened by waste along agri-food supply chains including production, manufacturing, distribution, retail and final consumption (Lebersorger \& Schneider, 2014; Stone \& Rahimifard, 2018). As such, it is critical that producers adopt new technologies to ensure efficient and effective management of their responsibilities.

Demartini et al. (2018) examined the innovation potential of Industry 4.0 (I4.0) technologies in the $\mathrm{AgF}$ sector. Process innovation opportunities identified include automating data collection and data visibility across the entire value chain. Yet, realising such opportunities requires an openness to the breadth and depth of I4.0 technologies (Büchi et al., 2020). Here, breadth reflects the number of pillars of Industry 4.0 enabling technologies implemented, while depth captures the number of stages in the value chain with these implemented technologies. The end result is seen in terms of flexibility, speed, increased production capacity, decreased errors and costs, an improved product quality and ability to meet customer needs. 
Different research themes associated with I4.0 have emerged. Benitez et al (2020) have described how I4.0 facilitates the transition from dyadic, linear or transactional-based supply chains to an ecosystem approach where value can be co-created among the firms. I4.0 challenges existing business models of product based firms and has the potential to enable new innovative ways of doing business (Frank et al., 2019; Müller et al., 2020). Yet, despite this potential for I4.0 to enhance producer competitiveness, Zambon et al. (2019) showed that, while there was an exponential increase in research papers published since 2014 on I4.0, none related to Agri-Food. Similarly, Demartini et al. (2018) found few publications containing the keywords "food" and "digital". Those which do, tend to focus on adoption of specific technologies for a specific purpose, such as installation of sensors to reduce food waste (Ramanathan et al, 2020). In fact, Müller et al. (2020) explicitly exclude food and agriculture due to their incomparability with other manufacturing sectors. Our paper addresses this gap by exploring the accepted range of I4.0 technologies and how they support product and process innovation, through the following research question: How does I4.0, as a set of enabling technology, influence core process innovation practice and product innovation outcomes in Agri-Food firms?

The paper is structured as follows: first we explore the I4.0 concept and the context of application, $\mathrm{AgF}$ sector. Then, we explore prior research to position the research question. We develop a conceptual framework to reflect that question. We present the research design and defend the selection of two AgF producers from Spain as case studies. We present the case data before reflecting on those data, presenting our contribution, drawing conclusions and identifying implications for management and further research.

\section{LITERATURE REVIEW}

Our interest is in understanding how I4.0 influences core process innovation practice and product innovation outcomes in Agri-Food producers. While this interest is of practical relevance, in order to position it theoretically, we draw on literature on I4.0. In particular, we introduce I4.0, examine its influences on innovation and in Agri-Food. Finally, we review literature at the intersections of these topics.

\subsection{Industry 4.0}

In 2013, the German Academy of Science and Engineering (Acatech), described I4.0 as the technical integration of human-machine connections through Cyber Physical Systems (CPS) and the use of the Internet of Things (IoT) in industrial processes (Kagermann et al., 2013). This $4^{\text {th }}$ industrial revolution involves advanced digitalization of manufacturing facilities, incorporating internet technologies, smart machines and products. From these roots, I4.0 grew and developed across industries. Industry 4.0 features a series of enabling technologies that Büchi et al. (2020) categorised into 10 pillars: advanced manufacturing solutions, augmented reality, internet of things, big data analytics, cloud computing, cyber security, additive manufacturing, simulation, horizontal and vertical integration and "other enabling technologies". This last pillar includes innovations towards superior product quality and reduced production waste in $\mathrm{AgF}$.

A key feature of I4.0 is how new technologies allow information integration and interoperability (Xu et al., 2018). This digital integration occurs horizontally and vertically. 
Horizontal integration relates to how IT systems are linked across manufacturing and planning within a firm, from incoming supplies, production, to shipping. Vertical integration describes how IT systems combine to deliver an end-to-end solution across producers to satisfy customer requirements. Finally, integrated production processes within producers complement global cooperation through adaptive, evolutionary and selforganising networks (Hozdić, 2015).

\subsection{Industry 4.0 as an Enabler of Innovation}

Adopting I4.0 technologies has the potential to go beyond traditional sources of competitive advantage to enable superior operational performance (Tortorella et al., 2019). I4.0 can be the driver of business model innovation, through enabling value creation, value capture and value offer elements of business models (Müller et al, 2018). Frank et al (2019) see I4.0 as a technology-push innovation approach which can lead to radical business model innovation for manufacturing companies.

Closer to the focus of this paper, I4.0 technologies can impact two forms of integration: between product and process innovation and, between I4.0 technologies and operational practices. Santos et al. (2017) explored the relationship between the product development process and I4.0. They noted that I4.0 enables integration of physical and digital technologies with the phases of product development. When this integration happens, development time can be reduced and problems prevented before manufacturing the prototype. Further, this early integration enables subsequent efficient allocation of machines, faster problem identification, production bottleneck reduction, defect reduction and improved customisation. Tortorella et al. (2019) noted that integration between product and process innovation helps in understanding customer needs and overcoming product design and use barriers, sharpens the market focus, enabling the producer to monitor continuously both its competitive position relative to changes in the market, to plan and communicate its product and service to the customer, and to measure its performance. Finally, since physical and digital technologies are integrated during the product development process, I4.0 facilitates greater supplier involvement (Hozdić, 2015; Santos et al., 2017; Tortorella et al., 2019). The resulting generation and treatment of data, and improved connection and traceability facilitate faster and more accurate new product creation and production (Kampker et al., 2016; Liao et al., 2017). This involvement and joint development through I4.0 lead to value co-creation which is particularly advantageous for resource constrained SMEs who may lack the skills do achieve this alone (Benitez, 2020).

Turing to the second form of integration, the potential for innovation in production and operations systems is significant (Hozdić, 2015). It facilitates faster production in accordance with individual customer requirements and production process optimization. I4.0 enables process connectivity and improved product traceability based on digital technologies and better internal process control (Buer et al., 2018). I4.0 is also a communicative action that mobilises actors to innovate collaboratively (Reischauer, 2018). Building on this focus, Tortorella et al. (2019) contended that purely technological adoption of I4.0 does not lead to the expected results. Rather, they found that lean production practices helped to install organisational habits and mindsets that favour systemic process 
improvements: “...the socio-technical organisational changes that coincide with [lean production] reinforce practices and behaviours which, when combined properly with today's technological advancements, enable companies to compete successfully under the, at first sight, paradoxical scenario where high-tech applications and human-based simplicity exist concurrently" (p. 875).

\subsection{Industry 4.0 in Agri-Food}

Despite increased mechanisation, I4.0 has not been utilised to its full potential in the AgriFood sector (De Silva \& De Silva, 2016) where the human operator retains a central role (Miranda et al., 2019). This observation is supported by Trivelli et al. (2019) who suggest potential applications for I4.0 technologies in $\mathrm{AgF}$ including monitoring, automation and decision support. However, AgF lags other industry sectors' I4.0 adoption, with Zambon et al. (2019) noting few innovative $\mathrm{AgF}$ producers realising its potential.

Yet, I4.0 can benefit the sector in different ways. Luque et al. (2017) identified the ability to adapt quickly to customer specifications; real-time information handling which enables improved decision making; traceability which leads to increased productivity and efficient resource use; and new business opportunities creation. They argue that I4.0 technologies enable food producers to respond to external pressures such as price by becoming more innovative, and to improve product traceability through interconnecting equipment and processes.

In conclusion, the societal importance of $\mathrm{AgF}$ is based on a responsibility to provide safe, secure and sustainable food. Yet, while much is known about I4.0 and its potential in industry, a gap remains in our understanding of how I4.0 influences process innovation and product performance in the $\mathrm{AgF}$ sector.

\section{THEORETICAL DEVELOPMENT AND RESEARCH MODEL}

To address the research question, we adopt a conceptual framework linking managerial processes through which innovation is carried out (Figure 1). The logic in the framework is that, as a process, innovation requires managing both core and enabling processes in order to realise competitiveness through new or improved products or manufacturing processes (Chiesa et al., 1996). Innovation challenges producers to manage and manipulate data to enable product and process innovation by new and different means. Here, I4.0 has characteristics which enable $\mathrm{AgF}$ producers to achieve competitive product and processbased competitive outcomes.

In the framework, the core processes of product and production process innovation and development are linked (Antonelli et al., 2012). Product development includes managing projects from concept to launch, integrating relevant functions and linking with manufacturing and engineering. Production process innovation and development involves formulating a manufacturing strategy, implementing new processes and continuous improvement (Chiesa et al., 1996). In the Agri-Food sector, technical and operational challenges faced in product and process development include generating novel recipes with natural ingredients and optimizing production processes (Coughlan et al., 2016). Many 
such challenges are overcome through open innovation models (Medeiros et al., 2016) which depend upon information sharing.

Figure 1. Conceptual Framework

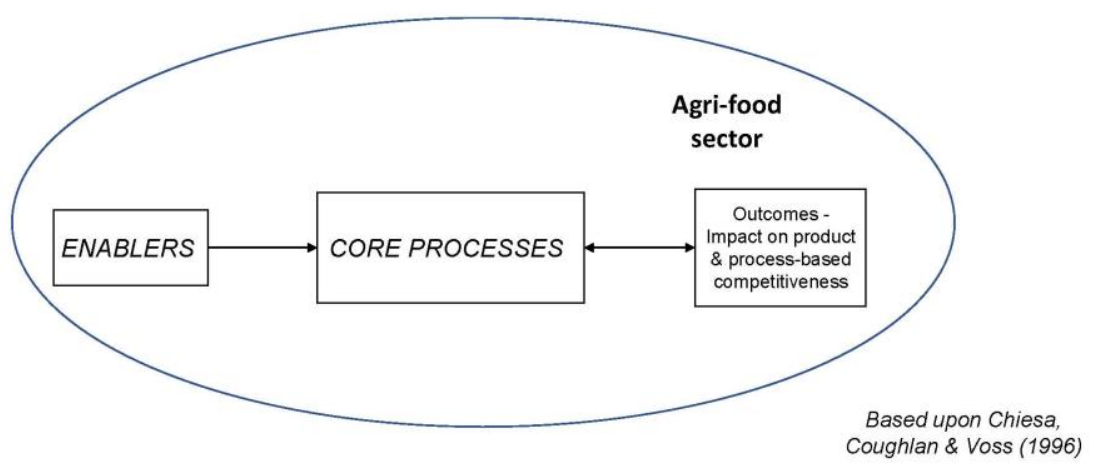

In the framework, I4.0 technologies act as enablers of the core innovation processes. These systems and tools include data acquisition, process traceability, digital automation with sensors, internet of things, cloud, big data and analytics (Benitez et al, 2020; Büchi et al, 2020; Dalenogare et al, 2018; Frank et al, 2019).

The framework identifies the outcomes of the innovation process in terms of impact on product and process-based competitiveness. Expected benefits enabled through I4.0 technologies include improved product customisation, product quality, process visualisation and control (Dalenogare et al, 2018). Expressed in term of Srinivasan et al. (2012), a food product may have functionality through its nutritional value, aesthetics through its presentation, and meaning through its safety. These elements of the total product design concept (TPDC) are linked with the customers' product experience.

\section{RESEARCH DESIGN}

To understand in-depth how I4.0 enables innovation practice and performance in AgriFood firms, we conducted a case-based study. Due to the novelty of the context in which the relationships are considered, case research was appropriate (Goffin et al, 2019). We describe our design including the research context, producer selection and data collection, and data analysis.

\subsection{Research Context}

The Agri-Food sector is the largest manufacturing sector in the EU, supporting more than 4.6 million jobs directly, with over $€ 1$ trillion in annual turnover and more than $€ 230 \mathrm{bn}$ 
added value (FoodDrink Europe, 2018). It transforms $72 \%$ of the agricultural raw materials produced in Europe. The sector comprises 294,000 firms, where 99\% are small and medium enterprises with diversified operations, profiles, scale and products. As a value chain, it is an interdependent and complex system connecting farmers with final consumers.

Trends in consumer preferences for food, apart from price, are shaped by factors related to health, social responsibility and convenience (ECSIP Consortium, 2016; FIAB, 2019). Consumer awareness of links between food consumption and health is rising as information becomes available on food ingredients and safety, allergies and intolerances, and maintaining a healthy lifestyle. Food safety is linked also to food contaminants and there is a growing interest in farming and processing practices including the use of additives, antibiotics and growth hormones. Socially responsible consumption choices are driven by sensitivity to how production-consumption proximity impacts climate change, public health, social and economic inequality, biodiversity, animal welfare, and resource utilisation. Finally, food convenience is demanded and linked to lifestyles which increasingly are mobile and faster paced.

The Spanish AgF sector is an appropriate context within which to explore the research question. Spain is a major European agricultural producer. With 23.7 million hectares and 989,800 farms, Spain ranks second in the EU and fourth for $\mathrm{AgF}$ production value (€43 billion) while gross value added is greater than that for its manufacturing industry (FIAB, 2019). As summarised in Table 1, technological innovation in Spanish firms varies by sector and the percentage of innovative firms in AgF industry is lower than other sectors and different in its focus. Further, despite consolidation in recent years, the average firm size in the Spanish AgF sector remains relatively small, being predominant the number of small and medium-sized enterprises. This crucial factor has shaped the adoption of digital solutions in the production process by the sector (Observatorio ADEI, 2016). It is the large producers that are most likely to incorporate technological innovations, encouraging the implementation of I4.0 in their wider supply chains.

Table 1. Technological innovation in Spanish firms (INE, 2019)

\begin{tabular}{|c|c|c|c|c|c|}
\hline & & Inno & on expenditure & (2017) & \\
\hline & $\begin{array}{c}\text { Innovative } \\
\text { firms } \\
(\%)\end{array}$ & $\begin{array}{l}\text { Total } \\
(€ ` 000)\end{array}$ & $\begin{array}{l}\text { R\&D } \\
\text { internal and } \\
\text { external (\%) }\end{array}$ & $\begin{array}{c}\text { Other } \\
\text { innovative } \\
\text { activities (\%) }\end{array}$ & $\begin{array}{l}\% \text { of turnover in } \\
\text { new and improved } \\
\text { products }\end{array}$ \\
\hline $\begin{array}{l}\text { Total manufacturing } \\
\text { industry }\end{array}$ & 23.93 & 7520448 & 67.76 & 32.24 & 22.20 \\
\hline $\begin{array}{l}\text { Food, beverages and } \\
\text { tobacco } \\
\text { (CNAE } 10,11,12 \text { ) }\end{array}$ & 18.46 & 713182 & 37.16 & 62.84 & 16.03 \\
\hline
\end{tabular}

$\mathrm{AgF}$ distribution channels in Spain are heterogeneous: for most products there are long channels with multiple intermediaries. Fresh products are distributed and sold through supermarkets and traditional stores. About supermarkets, five groups account for 57\% of sales and occupy $50 \%$ of the retail area. FIAB (2019) also remark as peculiarities of food 
distribution in Spain the importance of traditional stores in the sale of fresh products and the significant weight of the HoReCa sector compared to other European Union countries.

\subsection{Firm selection and data collection}

We took several steps in selecting the case firms. First, we explored I4.0 implementation in the Spanish AgF sector through industry reports (i.e. ECSIP, Consortium 2016; FoodDrink Europe, 2018; Martinez-Vicedo, 2017; Observatorio ADEI, 2016). They provided information on the degree of implementation of the different elements of I4.0 that were considered strategic in the sector towards improving firm competitiveness.

Subsequently, we met with an engineering consultancy that included AgF firms among its clients. The meeting aimed to obtain information on: specific I4.0 technologies implemented in $\mathrm{AgF}$ sub-sectors; companies which in recent years had invested in I4.0 technologies; and how I4.0 may have enhanced producer performance. This meeting also facilitated developing our interview guide for the case research. The guide focused on firm strategy and organization, I4.0 and implementation, and product and process innovation (Appendix A).

Based on the information obtained, we focused our study on those types of AgF firms that processed perishable natural raw materials considering how I4.0 may enable innovation. We anticipated that I4.0 might enable effective response to the natural variability of raw material, associated information generated at farm level and the information requirements of the production process. Additionally, it was expected that initiatives to control processing time would be in evidence.

To select two case firms as a literal replication (Voss, 2010), we considered, if, in the previous five years, they had invested in redesigning the plant layout for I4.0 implementation; if they had specialised personnel to apply and to understand the I4.0 technologies implemented; finally, their willingness to collaborate in the research. In addition, the producers had different customer and supply bases, and sizes. We crosschecked our requirements with senior management from the selected producers to confirm suitability. Table 2 provides summary information on each producer.

Table 2. Overview of Case producers (SABI, 2019)

\begin{tabular}{|l|c|c|}
\hline \multicolumn{1}{|c|}{ Producer details } & $\begin{array}{c}\text { Producer 1 } \\
\text { Meat }\end{array}$ & $\begin{array}{c}\text { Producer 2 } \\
\text { Citrus Fruit }\end{array}$ \\
\hline Activity & $\begin{array}{c}\text { Slaughterhouse and } \\
\text { cutting plant }\end{array}$ & $\begin{array}{c}\text { Handling and } \\
\text { distribution }\end{array}$ \\
\hline Year founded & 1989 & 1984 \\
\hline Employee numbers & 827 & 983 \\
\hline Exports & $10 \%(\mathrm{EU})$ & $48 \%(\mathrm{EU})$ \\
\hline
\end{tabular}

Both firms processed fresh products, and were compliant with security and quality regulations. They can be considered illustrative of two important sub-sectors of the Spanish Agri-food Industry: meat; and, fruit and vegetables. Both are large firms in sectors where 
$23.3 \%$ of meat firms and $13.7 \%$ of fruit firms have more than 500 employees (MAPA, 2018).

Also, possibilities for innovation were different in each firm. ECSIP Consortium (2016:51) estimated possibilities for innovation in the food and drink manufacturing sectors, differ by subsector. Both meat and fruit show possibilities in range extension; and in meat in relaunch.

We conducted in-depth semi-structured interviews in each producer with key informants involved in managing I4.0 and general plant management. Each producer nominated the interviewees after accepting the invitation to participate in the study and receiving the interview protocol. The protocol, introduced earlier and summarised in Appendix A, noted the main topics to be dealt with. In each case, we explored: what I4.0 technologies had been implemented, how and why; data and equipment integration; customer roles in implementation; other changes brought about by I4.0.

To assure construct validity and recognising that I4.0 can be understood differently, interviews began by directing the discussion towards a common understanding. Two researchers conducted each interview taking notes independently to enhance creative potential and confidence in the findings (Eisenhardt, 1989). All interviews lasted approximately 90 minutes. To assure information quality, we used a "snowballing technique", examining industry reports and web material related to the producer before and after visits. Finally, we took two steps to assist in validation. We reviewed the collected data with the consultancy firm which assisted in the evaluation of the I4.0 technologies and innovations introduced by each producer, with reference to the AgF sector. Then, we reengaged with each company to review our descriptions and reflections. As a result of these engagements, we were satisfied with the accuracy and validity of the case data.

\subsection{Data analysis}

Our data analysis followed two steps: data analysis within cases and then a search for cross-case patterns (Eisenhardt, 1989). Firstly, data were coded independently by the researchers who attended the interviews and, after discussing differences, information was checked by a researcher who had not attended. In this way, we achieved inter-coding

agreement. The data analysis progressed to identify factors influencing the impact of I4.0 on product and process innovation and on competitive product outcomes. The results describe and analyse the producers' experiences in their settings.

\section{FINDINGS \& RESULTS}

In this section, we describe each case firm, including the plant, products-customers, production scheduling and control, and observations on how innovation is impacted by I4.0.

\subsection{Firm 1. Beef-meat producer \\ 5.1.1 Plant description}

The plant is located in the Valencia region. The $55,000 \mathrm{~m}^{2}$ facility includes a beef slaughter line with a capacity of 100 animals per hour, a $40,000 \mathrm{~m}^{3}$ refrigerated warehouse 
and freezing tunnels with a capacity of 80 tonnes per day. The facilities are new and have been designed in accordance with strict food safety and traceability regulations.

The complete "farm-to-fork" cycle for meat is evident in the plant layout. Live animals from the farms enter the plant, are processed, and packaged meat products are shipped out. Most final products comprise individual pieces of meat, fully prepared for the retail consumer. To avoid contamination risks, the plant is laid out in independent zones. The entry area includes live animal reception, slaughter and rapid carcass cooling over 24-36 hours. The process then involves carcass cutting, warehousing for ageing over 10-14 days and, finally, cutting and packaging.

\subsubsection{Suppliers-Customers}

Live animals are purchased from farmers who guarantee traceability and product quality. Traceability information is transferred to the plant on purchase of the animal. Currently, $90 \%$ of production is for retail. The principal customer, a supermarket chain, specifies the cuts and packaging. The finished product is shipped daily to the customer's logistics centres for distribution to supermarkets. The remaining $10 \%$ of production is sold directly in other formats to butchers and restaurants, a relatively new line of business for the producer.

\subsubsection{Product Development Process}

Product innovations are driven by the principal customer and realised collaboratively. Once specifications for new products or new presentations of existing products are agreed, the producer adapts its production processes to achieve these. The engineering department is responsible for modifying existing processes and equipment, or acquiring new equipment. In those cases, the firm trains its people in any new procedures, with a focus on achieving process improvements, mostly keeping with cost reduction in mind.

\subsubsection{Production Scheduling and Control}

Normally, animals are slaughtered on the day of arrival at the facility. The throughput time for a carcass is 11-16 days, depending the ageing period specified by the customer. The daily production schedule is based on orders received from the principal customer specifying the meat to be used, cut, packaged and the logistics centre destination. Scheduling mismatches occur where cuts ordered by the main customer and those actually processed differ. These surplus cuts are sold to other customers, or used as a buffer to smooth production.

Compliance with food safety and traceability regulations is strict and drives process control and cost management. To facilitate traceability, each animal entering the plant is identifiable by a chip registering information on origin, age, breed, gender, housing and fattening. During subsequent production stages, all cuts are identified and linked to the animal. For this level of control, the producer has introduced software, developed internally, enabling compliant process management.

\subsubsection{Innovation influenced by $\mathbf{I}$ 4.0}

In each plant zone, the engineering team identifies process innovation opportunities and oversees implementation. To date, the main I4.0 technologies introduced by the producer 
are summarised in Table 3(a). These include IoT sensors to enable control and influence the meat quality at different process stages. Other I4.0 technologies increase automation of meat movement, cutting and packaging. Installing IoT sensors on equipment enables realtime process monitoring through an internally developed IT system. This has enabled the producer to demonstrate compliance with food safety requirements.

Table 3(a) Meat Producer Detailed Analysis

\begin{tabular}{|l|l|l|l|}
\hline $\begin{array}{l}\text { Industry 4.0 } \\
\text { Enablers }\end{array}$ & Core Processes & $\begin{array}{l}\text { Expected Process-based } \\
\text { Competitiveness }\end{array}$ & $\begin{array}{l}\text { Expected Product-based } \\
\text { Competitiveness }\end{array}$ \\
\hline $\begin{array}{l}\text { Advanced } \\
\text { Solutions }\end{array}$ & Process Innovation & $\begin{array}{l}\text { Production Flexibility } \\
\text { Increase Output Capacity } \\
\text { Higher Machine Utilisation } \\
\text { Improved Yield } \\
\text { Increased Customer } \\
\text { Satisfaction }\end{array}$ & $\begin{array}{l}\text { Functionality } \\
\text { Aesthetics }\end{array}$ \\
\hline Internet of Things & $\begin{array}{l}\text { Product Innovation } \\
\text { Process Innovation }\end{array}$ & Improved Yield & $\begin{array}{l}\text { Functionality } \\
\text { Meaning }\end{array}$ \\
\hline Big Data Analytics & Process Innovation & Improved Yield & $\begin{array}{l}\text { Functionality } \\
\text { Meaning }\end{array}$ \\
\hline Cyber Security & $\begin{array}{l}\text { Product Innovation } \\
\text { Process Innovation }\end{array}$ & $\begin{array}{l}\text { Improved Yield } \\
\text { Increased Customer } \\
\text { Satisfaction }\end{array}$ & Meaning \\
\hline $\begin{array}{l}\text { Horizontal \& } \\
\text { Vertical Integration }\end{array}$ & $\begin{array}{l}\text { Product Innovation } \\
\text { Process Innovation } \\
\text { Product }\end{array}$ & $\begin{array}{l}\text { Prototype Speed } \\
\text { Increase Output Capacity } \\
\text { Higher Machine Utilisation } \\
\text { Improved Yield } \\
\text { Increased Customer } \\
\text { Satisfaction }\end{array}$ & Meaning \\
\hline $\begin{array}{l}\text { Other Enabling } \\
\text { Technologies }\end{array}$ & Process Innovation & $\begin{array}{l}\text { Increased Customer } \\
\text { Satisfaction }\end{array}$ & Meaning \\
\hline
\end{tabular}

\subsection{Firm 2. Citrus fruit producer}

\subsubsection{Plant description}

The citrus fruit plant is located also in the Valencia region. The $50,000 \mathrm{~m}^{2}$ production facility has a capacity is 1,000 tonnes/day. The facilities are new and their design conforms to the safety requirements for fresh food products, isolating process stages to avoid crosscontamination.

Consistent with industry practice, the plant is laid out in three areas: pre-calibrate, cold storage, treatment and packaging. Incoming deliveries from farms enter the pre-calibration area after weighing and control. Here, they pass through primary selection and cleaning. Then, they move to the refrigerated area for storage and de-greening if needed. This area serves as semi-processed product buffer storage to regulate the flow to the stage following. From there, the fruit is routed to the treatment line. Here, further selection and cleaning is carried out, along with calibration and packing according to customer specifications. These operations are performed with minimal human involvement. The packaged fruit is prepared for dispatch and stored in refrigerated rooms until loaded onto trucks for delivery. 


\subsubsection{Suppliers-Customers}

Eighty per cent of the incoming fruit is sourced from farms where the firm has full access to data on the farming process, like fertilisers, pesticides and other chemicals applied during growing and harvesting. Through the firm's IT system, critical data for product safety and traceability are available in real-time and advise the farms on appropriate actions. Data on the other $20 \%$ of incoming fruit are requested directly from the supplier and, on receipt, entered manually into the IT system.

Clients are local and international retail distribution chains. $80 \%$ of the production is exported to Europe, through the producer's logistics centre in Perpignan. The Madrid logistics centre serves the domestic market. Finally, any fruit that cannot be sold as fresh is sent to an associated juice extraction firm.

\subsubsection{Product Development Process}

Introducing new fruit varieties has enabled the firm to extend the sales window, reducing supply seasonality. This capability is important because it assures the supply to the supermarket chains for longer periods, facilitating purchasing management. Further, new presentation formats have been developed which reduce handling at the distribution centres. Some customers demand bespoke solutions. Recently, a distribution chain requested a specialised packaging format, which required new equipment and packaging materials. In those cases, the development process was carried out collaboratively with equipment suppliers, enabling the producer to successfully adapt to the new formats.

\subsubsection{Production Scheduling and Control}

The target is for fruit to be processed within 24 hours of receipt, except where de-greening is necessary. Occasionally, deliveries to the customer may be delayed by a day if it is necessary to consolidate multiple orders comprising different fruit varieties and/or with different final finishes. Customer requirements for fresh fruit differ depending on the country destination and on the client. Data on chemicals used in the field by suppliers are combined with those gathered from incoming inspection by the firm. These data determine the processes and treatments in the plant. Data on internal processing, storage and subsequent processing are recorded for each individual batch in QR codes. The firm stores all data for food security and traceability reasons, and as a precaution against potential claims. In practice, customers rarely request these data. The data are used also to estimate production costs and as input to the producer's continuous improvement programme.

\subsubsection{Innovation influenced by $\mathbf{I} 4.0$}

The management team has driven I4.0 implementation to increase its capacity for information management and process control, thus better meeting customer requirements and food safety regulations. To date, the main I4.0 technologies introduced by the producer are summarised in Table 3(b). The real-time status of fruit and equipment is enabled through IoT sensors. Increased automation and reduced human intervention reduces process variability. Furthermore, I4.0 has enabled the producer to adapt quickly to new customer packaging specifications. Many I4.0 technologies are installed and managed by the producer's IT department. It has a project underway to move to open platforms to make data more user friendly and to enable easy visualisation. 
Table 3(b) Fruit Producer Detailed Analysis

\begin{tabular}{|l|l|l|l|}
\hline $\begin{array}{l}\text { Industry 4.0 } \\
\text { Enablers }\end{array}$ & Core Processes & $\begin{array}{l}\text { Expected Process- based } \\
\text { Competitiveness }\end{array}$ & $\begin{array}{l}\text { Expected Product-based } \\
\text { Competitiveness }\end{array}$ \\
\hline $\begin{array}{l}\text { Advanced } \\
\text { Solutions }\end{array}$ & $\begin{array}{l}\text { Product Innovation } \\
\text { Process Innovation } \\
\text { Product } \\
\text { Development }\end{array}$ & $\begin{array}{l}\text { Production Flexibility } \\
\text { Prototype Speed } \\
\text { Increase Output Capacity } \\
\text { Higher Machine Utilisation } \\
\text { Improved Yield } \\
\text { Increased Customer } \\
\text { Satisfaction }\end{array}$ & $\begin{array}{l}\text { Functionality } \\
\text { Aesthetics }\end{array}$ \\
\hline Internet of Things & $\begin{array}{l}\text { Product Innovation } \\
\text { Process Innovation }\end{array}$ & Improved Yield & $\begin{array}{l}\text { Functionality } \\
\text { Meaning }\end{array}$ \\
\hline Big Data Analytics & Process Innovation & $\begin{array}{l}\text { Increase Output Capacity } \\
\text { Higher Machine Utilisation } \\
\text { Improved Yield }\end{array}$ & $\begin{array}{l}\text { Functionality } \\
\text { Meaning }\end{array}$ \\
\hline Cyber Security & Product Innovation \\
Process Innovation & $\begin{array}{l}\text { Improved Yield } \\
\text { Increased Customer } \\
\text { Satisfaction }\end{array}$ & Meaning \\
\hline $\begin{array}{l}\text { Horizontal \& } \\
\text { Vertical Integration }\end{array}$ & $\begin{array}{l}\text { Product Innovation } \\
\text { Process Innovation }\end{array}$ & $\begin{array}{l}\text { Prototype Speed } \\
\text { Increase Output Capacity } \\
\text { Higher Machine Utilisation } \\
\text { Improved Yield } \\
\text { Increased Customer } \\
\text { Satisfaction }\end{array}$ & Meaning \\
\hline $\begin{array}{l}\text { Other Enabling } \\
\text { Technologies }\end{array}$ & Process Innovation & $\begin{array}{l}\text { Increased Customer } \\
\text { Satisfaction }\end{array}$ & Meaning \\
\hline
\end{tabular}

\section{DISCUSSION}

We return to the research question: How does I4.0, as a set of enabling technologies, influence core process innovation practice and product innovation outcomes in Agri-Food firms? The AgF sector faces significant challenges in managing product and process innovation. Consumers are changing in how they appreciate food, especially in healthiness, nutritional content, sustainability and convenience. This food functionality requires technological supremacy, analytical knowledge, interactions with suppliers and customers, and consumer trust (Khan et al., 2013). FOOD2030, the EU research and innovation policy, calls for more investment to find solutions to the challenges facing food systems. It suggests research and innovation to future-proof how food is produced through smart farming and production, and processed using novel manufacturing technologies. In its response, FoodDrink Europe, the industry association, has recommended focusing R\&D on modernisation through digitalisation, including IoT and Big Data. It has called for increased focus on food safety, including traceability, to increase consumer trust in food processing (FoodDrink Europe, 2019).

These recommendations are not new. Much innovation in the AgF sector has been linked to production cost minimization (Bigliardi \& Galati, 2013), building on in-house knowledge and dependence on specialized embodied-technology suppliers (Trippl, 2010). Further, AgF producers have become more innovation focused through developments in 
biotechnology and process control improvements that exploit economies of scale, guarantee food safety, variety, and quality (Traill \& Meulenberg, 2002). Such product and process innovations are often interdependent (Triguero et al., 2013) and have required cooperation with other supply chain actors. This requirement has brought new organizational challenges (Bigliardi \& Galati, 2013) and intensive resource requirements (Garcia Martinez et al., 2014). We reflect on the evidence of these challenges in the case data.

\subsection{The Scope of Industry 4.0 in the Agri-Food Cases}

I4.0 technologies include data acquisition, process traceability, digital automation with sensors, internet of things, cloud, big data and analytics (Ayala, 2019; Benitez et al, 2020; Büchi et al, 2020; Dalenogare et al, 2018; Frank et al, 2019), which are evident in both meat and fruit firms. The real benefit of these technologies how they allow horizontal and vertical integration (Xu et al., 2018). Horizontal integration links across manufacturing and planning within the firms, from incoming fruit and animal supplies, processing, to shipping. The real value for customers is the vertical integration, which enables end-to-end traceability of food products.

In the two cases there is evidence of data now available to the firms through I4.0, on how I4.0 facilitates data use, the impact data use on food and product characteristics, and the resulting innovation. This evidence is summarised in Tables 3(a) and 3(b). The logic embedded in these tables is consistent with the conceptual framework in Figure 1: I4.0 enables producers to manage and manipulate data during product and process innovation process. The competitive product outcomes are interpretable in terms of the total product development concept (Srinivasan et al., 2012).

We observed similarities and differences between the two firms. In the meat firm, the initial information on raw material is concentrated, each animal is different but everything concerning an animal is known precisely. In the fruit one, on the contrary, although the treatment received in each parcel is known, the variability within it is greater and the control of the lot more problematic, needing more control measures to achieve the same level of information and homogeneity of the final product. On the other hand, the process in the meat firm is a linear flow process. The carcasses are similar and are processed following a similar way until the final cut is reached, while in the fruit, it is as a batch process. Each variety requires adjustments in the packing line, no varieties and/or species can be mixed. The great similarity is that in both cases the basic concern is to keep under control the traceability of the product, both for food safety issues (ultimately responsible for possible health problems) and for strategic management of suppliers and customers.

The I4.0 technologies incorporated by the two producers include advanced manufacturing solutions, IoT and other enabling technologies specific to the food industry (Büchi et al., 2020). Big data analytics enables food safety and traceability, although, the full potential has yet to be fully exploited in decision-making. Other I4.0 enablers described by Büchi's et al (2020) were not evident in the firms. 
Regarding horizontal integration, both producers have high internal connectivity, allowing operational outcomes such as reduced set-up costs, flexibility, fewer errors and lower machine downtime, leading to increased customer satisfaction. Vertical integration with customers is evident in the meat producer, while for the citrus fruit producer, the integration is focused more on providers and driven by European traceability regulations. Cyber security is maintained in both producers through developing Big Data applications internally so reducing dependence on suppliers.

\subsection{Industry 4.0 as an Enabler of Innovation in the Agri-Food Cases}

In the AgF sector, raw materials are natural and fresh. In addition, requirements for food are changing and specified by customers, who may be retailers responding to changing regulations, consumer expectations and competition. Here, I4.0 enables timely and reliable data availability for producers and customers which improve plant efficiency, so reducing time to market. Table 4 outlines how, in the two cases, I4.0 enables responses to new customer requirements through a range of process innovations. These innovations result in product outcomes which enhance the functionality, aesthetics and meaning of the delivered products.

Table 4. Food product dimensions enhanced by I4.0

\begin{tabular}{|c|c|c|c|c|}
\hline $\begin{array}{l}\text { New customer } \\
\text { requirements }\end{array}$ & $\begin{array}{c}\text { By means of } \\
\text { (I4.0 in general) }\end{array}$ & $\begin{array}{l}\text { I4.0 is facilitating the } \\
\text { case firms through }\end{array}$ & $\begin{array}{l}\text { Product Outcome } \\
\text { (Food characteristics) }\end{array}$ & $\begin{array}{c}\text { Product } \\
\text { dimension }\end{array}$ \\
\hline \multirow{3}{*}{$\begin{array}{l}\text { - Information about } \\
\text { - Origin } \\
\text { - Treatment } \\
\text { - Nutrition } \\
\text { - Health and well- } \\
\text { being } \\
\text { - Environmental } \\
\text { impact } \\
\text { - Ease of use in the } \\
\text { different links of the } \\
\text { chain }\end{array}$} & \multirow[t]{3}{*}{$\begin{array}{l}\text { Data Integration } \\
\text { - From } \\
\text { suppliers to } \\
\text { customers } \\
\text { - Controlling } \\
\text { the } \\
\text { production } \\
\text { process }\end{array}$} & $\begin{array}{l}\text { - Data availability for } \\
\text { producers and } \\
\text { customers } \\
\text { - Management of plant } \\
\text { operations } \\
\text { - Reducing time to } \\
\text { market }\end{array}$ & $\begin{array}{l}\text { - Higher basic product } \\
\text { information } \\
\text { - Improved food } \\
\text { security } \\
\text { - Trust in food safety }\end{array}$ & Functionality \\
\hline & & $\begin{array}{l}\text { Meat producer: } \\
\text { - Better accommodation } \\
\text { of client specifications } \\
\text { - Process control to } \\
\text { improve meat } \\
\text { appearance and } \\
\text { presentation } \\
\text { Fruit producer: } \\
\text { - Process control to } \\
\text { improve fruit } \\
\text { appearance } \\
\text { - Faster throughput time }\end{array}$ & $\begin{array}{l}\text { - Product presentation } \\
\text { and packaging } \\
\text { - Individual experience } \\
\text { via senses (smell, } \\
\text { touch, taste) }\end{array}$ & Aesthetics \\
\hline & & $\begin{array}{l}\text { - Transparency in } \\
\text { materials sourcing and } \\
\text { processing }\end{array}$ & $\begin{array}{l}\text { - } \text { Trust } \\
\text { - Additional product } \\
\text { information } \\
\text { - Sustainability } \\
\text { considerations }\end{array}$ & Meaning \\
\hline
\end{tabular}


More specifically in the meat producer, I4.0 enables better adaptation to changing customer specifications. Improved process control enables enhanced meat appearance and presentation. For the fruit producer, I4.0 enables process control and throughput time reduction, thereby retaining freshness and improving taste.

Meat and fruit are products characterised by functionality, aesthetics and meaning (Srinivasan et al., 2012). I4.0 helps producers to develop, produce and enhance these dimensions where functionality is defined by taste and nutritional characteristics which depend on processing speed and treatment. Integrating information from suppliers and customers and the production control enabled by I4.0 together lead to improved functionality. Aesthetics, which depend on how the product is presented and packaged, is better matched to customer demands if producers integrate customer requirements with supplier and production information. The product meaning is enhanced through traceable farm-to-fork information which increases consumer trust.

For I4.0 to work, there needs to be a relationship between customer and supplier. Many customers of the two producers are "good customers" (Lynch et al., 2016). Echoing Tortorella et al. (2019), they engage and demand an open interaction with the producers. They expect useful and usable information at product development, processing and delivery stages. The producers are "good suppliers" (Lawson et al., 2015). They respond to customer demands, develop specifications and deliver a product with transparency. This responsiveness is enabled by real-time information on incoming raw materials and from the production process. Through deploying I4.0 technologies, the producers develop the information systems, manage and exploit the information for process improvement and customer relationship purposes. With these capabilities, the producers work with new ideas and new technology to create competitiveness for their customers. For the fruit producer, real-time data from fruit farms on pesticide use enables fast fruit routing on arrival at the plant. For the meat processor, the chip on the live animal enables "farm-to-fork" traceability. As such, consistent with Kampker et al. (2016) and Tortorella et al. (2019), I4.0 facilitates greater supplier involvement in the customer's production process, reduces administrative burdens and speeds up communication. Further, the fruit producer has been able to adapt quickly to emerging customer requirements such as new packaging design. Again, this observation is consistent with Santos et al. (2017) who suggest that I4.0 technologies reduce development time and enable greater product customisation.

Finally, I4.0 can enable the redesign of business models both from the customer perspective through new digital solutions for customers (e.g. embedded technology in products) and for operations, where digital technologies can lead to process efficiencies (Dalenogare et al., 2018; Müller et al., 2018; Frank et al., 2019). Our findings indicate the latter is clearly evident in the meat and fruit firm, where eight of the Dalenogare et al (2018) expected benefits of I4.0 are found. While I4.0 has enhanced traceability for fruit and meat customers, the level of business model innovation through embedded technology or servitisation was not explored in our study. 


\section{CONCLUSIONS, MANAGERIAL IMPLICATIONS AND LIMITATIONS}

\subsection{Consolidation and theoretical contribution}

This paper has presented evidence of a relationship between I4.0 implementation, innovation and competitive outcomes. Reflections on this evidence contribute to the literature on I4.0 and lead to actionable insights.

At the outset, we set out to address the research question. Our investigation was visualised in Figure 1. On completing the two cases and reflecting on the data, we have populated that original framework and Figure 2 now captures our new insights. The fundamental relationships remain intact. However, through combining our empirical data with Büchi et al. (2020) proposals, we deepen the meaning and operationalisation of each key area. The insights are captured in Figure 2.

Figure 2. Updated Conceptual Framework

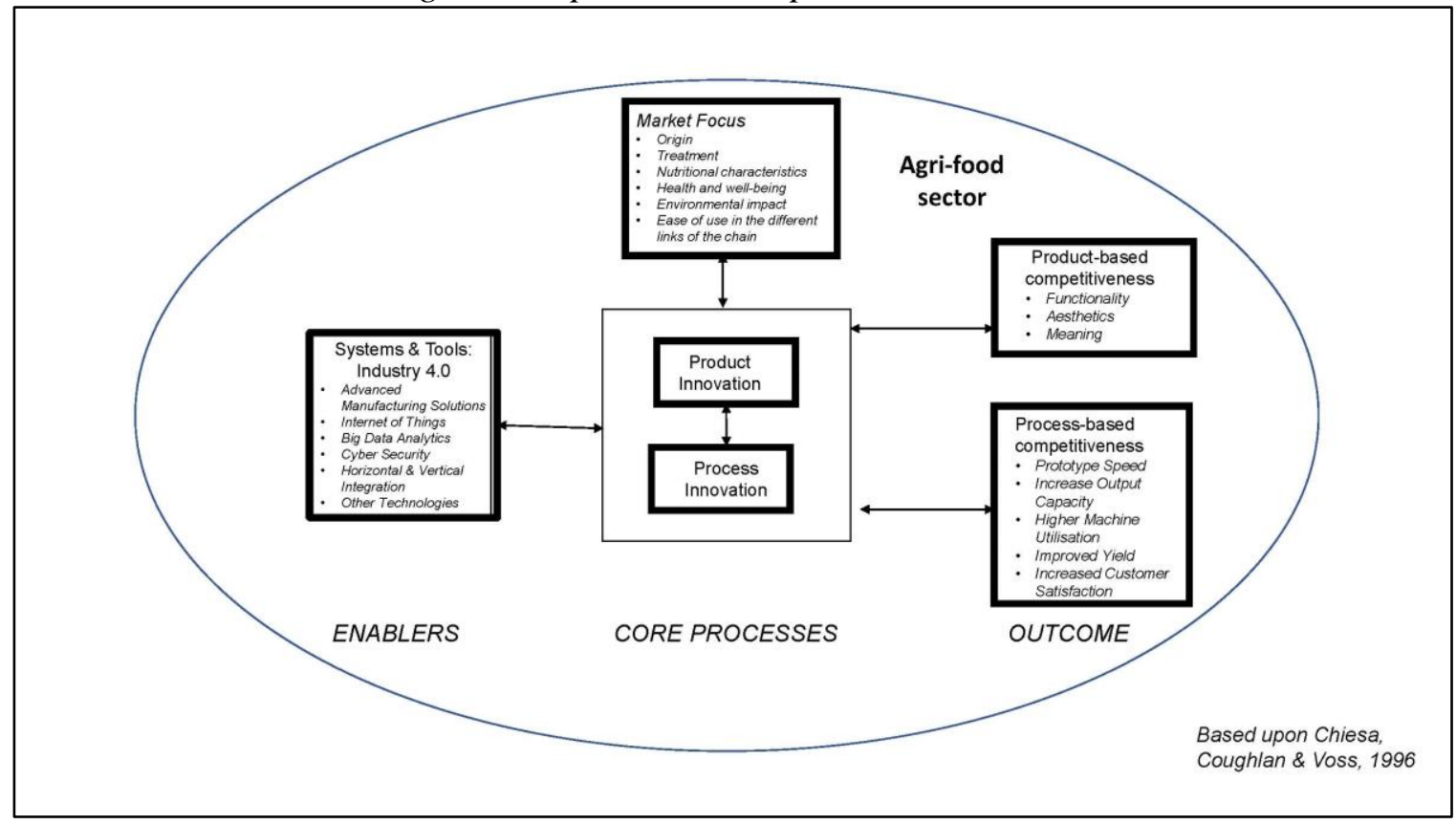

Luque et al. (2017) identified the potential of I4.0 for the AgF sector, including the ability to adapt quickly to customer specifications; real-time information handling; traceability and new business opportunities creation. Similarly, Trivelli et al. (2019) suggest potential applications for I4.0 technologies in AgF including monitoring, automation and decision support. Our research findings align with these contentions, where I4.0 facilitates new packaging design, process monitoring, traceability and product range extension. The connectivity and data also lead to opportunities for both producers. Greater efficiency and productivity are achievable through reduced set-up costs, errors, and machine downtimes. This leads to superior product quality and less production waste, enabling price competitiveness. Increased flexibility in each producer enables fast adaptation to changing customer specifications. The competitive product outcomes enabled by I4.0 are seen in functional terms: higher basic product information, improved food security and higher trust in food safety. Aesthetically, product presentation and packaging are improved, enhancing 
smell, touch, taste. Finally, deeper trust, additional product information and details on sustainability criteria enhance the meaning of food.

So, we conclude with the following proposition: I4.0 is an enabling technology for innovation in the $\mathrm{AgF}$ firms and improves the competitiveness of the delivered product and associated consumer experience. Changing customer requirements are demanding new and quicker responses from food producers. Our findings show how I4.0 is enabling producers to compete through innovation in process and product outcomes evident in product function, meaning and aesthetics.

\subsection{Implications for Management}

Adapting to new customer and European regulatory requirements to enhance food safety and traceability requires data. Further, the UK departure from the EU adds complexity to the sector with increasing demands for regulatory information on food functionality, aesthetics and meaning. In addition, the disruption to food harvesting and supply arising from the COVID-19 pandemic presents challenges for distribution, traceability and quality. Yet, Agri-Food producers innovate, operate and compete in a data rich environment. These data come from suppliers, internal process owners and customers. The emerging opportunity for producers is to exploit I4.0 to accommodate these many complexities so that consumers maintain confidence in their food. To realise this opportunity requires that a producer recognises that I4.0 is not a single technology and that each technology has the potential to impact its core innovation processes in different ways. In turn, when deployed systematically and in an integrated way, these technologies impact two critical bases for competitiveness, operations process performance and product characteristics.

\subsection{Opportunities for Future Research}

As noted at the outset, the European $\mathrm{AgF}$ sector is economically important. This paper has explored I4.0 implementation in two Spanish producers. While illustrative, the insights are by no means generalizable across the sector and to other countries. Engaging in the study has benefitted the case firms, especially through capturing and codifying their practices. The dissemination may be of value to the broader sector. However, the evidence explored and continuing complexities in the sector form a basis for further sectoral and international comparisons in relation to I4.0 implementation.

Büchi et al. (2020) describe opportunities arising from I4.0. In the two producers explored, these opportunities are achieved through real-time, reliable data from raw materials suppliers and the production processes. They are enabled by intelligent systems incorporated in I4.0 technologies. Value added for the consumer arises from greater visibility from "farm-to-fork" and processing. Further, Benitez et al (2020) proposed a three stage lifecycle or maturity model of I4.0 ecosystem development. It would appear that the fruit and meat firms are currently at the first (birth) phase. This level of maturity may suggest further or additional benefits for firms in the sector beyond those identified, an opportunity which is worth exploring in future research.

Finally, as mentioned in the literature, there are opportunities for I4.0 enabled business model innovation. As the focus of our paper was on product/process innovation, we did not 
explore the levels of business model innovation. However, having demonstrated the capabilities of I4.0 in this the $\mathrm{AgF}$ sector, it raises the questions of the impact on $\mathrm{AgF}$ business models in a post-Covid/with-Covid and BREXIT world.

\section{REFERENCES}

Antonelli, C., Crespi, F., \& Scellato, G. (2012). Inside innovation persistence: New evidence from italian micro-data. Structural Change and Economic Dynamics, 23(4), 341-353. https://doi.org/10.1016/j.strueco.2012.03.002

Benitez, G.B., Ayala, N.F. \& Frank, A.G. (2020). Industry 4.0 innovation ecosystems: an evolutionary perspective on value cocreation. International Journal of Production Economics, p.107735.

Bigliardi, B., \& Galati, F. (2013). Models of adoption of open innovation within the food industry. Trends in Food Science and Technology, 30(1), 16-26. https://doi.org/10.1016/j.tifs.2012.11.001

Büchi, G., Cugno, M. \& Castagnoli, R. (2020). Smart factory performance and Industry 4.0. Technological Forecasting and Social Change, 150, 119790.

Buer, S.-V., Strandhagen, J. O., \& Chan, F. (2018). The link between Industry 4.0 and lean manufacturing: mapping current research and establishing a research agenda. International Journal of Production Research, 56(8), 2924-2940. https://doi.org/10.1080/00207543.2018.1442945org/10.1080/00207543.2018.14429 45

Chiesa, V., Coughlan, P., \& Voss, C. A. (1996). Development of a technical innovation audit. Journal of Product Innovation Management, 13(2), 105-136. https://doi.org/https://doi.org/10.1016/0737-6782(95)00109-3

Costa, C., Antonucci, F., Pallottino, F., Aguzzi, J., Sarriá, D. \& Menesatti, P. (2013). A Review on Agri-food Supply Chain Traceability by Means of RFID Technology. Food Bioprocess Technology, 6, 353-366. DOI 10.1007/s11947-012-0958-7

Coughlan, P., Coghlan, D., O'Leary, D., Rigg, C., \& Barrett, D. (2016). Supporting sustainability through developing a learning network among traditional food producers: Applications of action learning. In Organizing for sustainable effectiveness, 5, 59-81. https://doi.org/10.1108/S2045-060520160000005011

Dalenogare, L. S., Benítez, G. B., Ayala, N. F. \& Frank, A. G. (2018). The expected contribution of Industry 4.0 technologies for industrial performance. International Journal of Production Economics, 204, pp. 383-394.

De Silva, P. C. P., \& De Silva, P. C. A. (2016). Ipanera: An industry 4.0 based architecture for distributed soil-less food production systems. 2016 Manufacturing \& Industrial Engineering Symposium (MIES), 1-5. https://doi.org/10.1109/MIES.2016.7780266

Demartini, M., Pinna, C., Tonelli, F., Terzi, S., Sansone, C., \& Testa, C. (2018). Food industry digitalization: from challenges and trends to opportunities and solutions. IFAC-PapersOnLine. https://doi.org/10.1016/j.ifacol.2018.08.337 https://doi.org/10.1016/j.technovation.2018.05.005

ECSIP Consortium. (2016). The competitive position of the European food and drink industry. Final report. In E. Consortium \& E. C. and S. I. Policy (Eds.), Publications Office of the European Union. https://doi.org/doi:10.2826/039661 
Eisenhardt, K. M. (1989). Building Theories from Case Study Research. The Academy of Management Review, 14(4), 532-550. https://doi.org/https://doi.org/10.5465/amr.1989.4308385

FIAB. (2019). Marco estratégico para la industria de alimentación y bebidas. Retrieved from https://www.mapa.gob.es/es/alimentacion/temas/industriaagroalimentaria/marco-estrategico/

FoodDrink Europe (2018). Data \& Trends EU Food and Drink Industry. Fooddrink Europe. https://www.fooddrinkeurope.eu/publication/data-trends-of-the-europeanfood-and-drink-industry-2018/.

FoodDrink Europe (2019). FoodDrinkEurope's views on Horizon Europe. Retrieved from https://www.fooddrinkeurope.eu/publication/fooddrinkeuropes-views-on-horizoneurope/

Frank, A. G., Dalenogare, L. S. \& Ayala, N. F. (2019). Industry 4.0 technologies: Implementation patterns in manufacturing companies. International Journal of Production Economics, 210, pp.15-26.

Garcia Martinez, M., Lazzarotti, V., Manzini, R., \& Sánchez García, M. (2014). Open innovation strategies in the food and drink industry: determinants and impact on innovation performance. International Journal of Technology Management, 66(2/3), 212. https://doi.org/10.1504/ijtm.2014.064588

Goffin, K., Åhlström, P., Bianchi, M., \& Richtnér, A. (2019). State-of-the-art: The quality of case study research in innovation management. Journal of Product Innovation Management, 36(5), 586-615. https://doi.org/10.1111/jpim.12492

Hozdić, E. (2015). Smart factory for industry 4.0: A review. International Journal of Modern Manufacturing Technologies, VII(1), 28-35. https://doi.org/10.1016/j.procir.2016.03.162

INE (2019) Encuesta sobre innovación en las empresas 2017. Instituto nacional de estadística. Madrid. $\quad$ Retrived from https://www.ine.es/dyngs/INEbase/es/operacion.htm?c=Estadistica_C\&cid=125473 $6176755 \&$ menu $=$ ultiDatos \&idp $=1254735576669$

Kagermann, H., Wahlster, W. \& Helbig, J. (2013). Recommendations for implementing the strategic initiative INDUSTRIE 4.0. Final Report of the Industrie $4.0 \mathrm{WG}$, p. 82. https://en.acatech.de/publication/recommendations-for-implementing-the-strategicinitiative-industrie-4-0-final-report-of-the-industrie-4-0-working-group/

Kampker, A., Deutskens, C., Heimes, H., Ordung, M., \& Haunreiter, A. (2016). Using emobility as an enabler for a fast and lean product development to optimize the return of engineering with the example of lithium-ion battery. Procedia CIRP, 50, 166-172. https://doi.org/https://doi.org/10.1016/j.procir.2016.05.085

Khan, R. S., Grigor, J., Winger, R., \& Win, A. (2013). Functional food product development - Opportunities and challenges for food manufacturers. Trends in Food Science and Technology, 30(1), 27-37. https://doi.org/10.1016/j.tifs.2012.11.004

Lawson, B., Krause, D., \& Potter, A. (2015). Improving Supplier New Product Development Performance: The Role of Supplier Development. Journal of Product Innovation Management, 32(5), 777-792. https://doi.org/10.1111/jpim.12231

Lebersorger, S. \& Schneider, F. (2014). Food loss rates at the food retail, influencing factors and reasons as a basis for waste prevention measures. Waste Management 34, 1911-1919. 
Liao, Y., Deschamps, F., Loures, E. de F. R., \& Ramos, L. F. P. (2017). Past, present ,and future of Industry 4.0 - a systematic literature review and research agenda proposal. International Journal of Production Research, 55(12), 3609-3629. https://doi.org/10.1080/00207543.2017.1308576

Luque, A., Peralta, M. E., de las Heras, A., \& Córdoba, A. (2017). State of the Industry 4.0 in the Andalusian food sector. Procedia Manufacturing, 13, 1199-1205. https://doi.org/10.1016/j.promfg.2017.09.195

Lynch, P., O’Toole, T., \& Biemans, W. (2016). Measuring Involvement of a Network of Customers in NPD. Journal of Product Innovation Management, 33(2), 166-180. https://doi.org/10.1111/jpim.12293

MAPA (2018). Informe sector industria cárnica y Preparación y conservación de frutas y hortalizas. Ministerio de agricultura y pesca, alimentación y medio ambiente. Madrid

Martínez-Vicedo, J. (2017). Industria 4.0: Transformación Digital, Small data, Ecommerce." AINIA Insights Octubre, \#2. https://doi.org/10.1017/CBO9781107415324.004.

Medeiros, G., Binotto, E., Caleman, S., \& Florindo, T. (2016). Open innovation in agrifood Chain: A systematic review. Journal of Technology Management and Innovation, Vol. 11, pp. 108-116. https://doi.org/10.4067/S0718-27242016000300013

Miranda, J., Ponce, P., Molina, A., \& Wright, P. (2019). Sensing, smart and sustainable technologies for Agri-Food 4.0. Computers in Industry, 108, 21-36. https://doi.org/10.1016/j.compind.2019.02.002

Müller, J. M., Buliga, O. \& Voigt, K.I. (2018). Fortune favors the prepared: How SMEs approach business model innovations in Industry 4.0. Technological Forecasting and Social Change, 132, pp.2-17.

Müller, J. M., Buliga, O. \& Voigt, K. I. (2020). The role of absorptive capacity and innovation strategy in the design of industry 4.0 business Models-A comparison between SMEs and large enterprises. European Management Journal. Article in Press

Observatorio ADEI. (2016). Digitalización y sectores productivos en España (II). Retrieved from www.afi.es

Ramanathan, R., Kelly, D., Gardiner, B., Corkery, G., Ajmal, T., Duffy, W. \& Condell, J. (2020). Agriculture 4.0: A review of sensors for reducing waste in food logistics and supply chains. Book of proceedings, EurOMA conference 2020. Warwick, pp. 127136

Reischauer, G. (2018). Industry 4.0 as policy-driven discourse to institutionalize innovation systems in manufacturing. Technological Forecasting and Social Change, 132, pp. 26-33.

SABI (2019.) Sistema de Análisis de Balances Ibéricos (SABI). Bureau van Dijk Electronic Publishing. Retrived from https://sabi.bvdinfo.com/Search.QuickSearch.serv?_CID=1\&context=NE7GGYJHX VL37CR\&loginpostback=true\&ssotoken=OwUNh9RNKUkCFx3kUGav7g\%3d\%3d

Santos, K., Loures, E., Piechnicki, F., \& Canciglieri, O. (2017). Opportunities Assessment of Product Development Process in Industry 4.0. Procedia Manufacturing, 11, 13581365. https://doi.org/10.1016/j.promfg.2017.07.265

Srinivasan, R., Lilien, G. L., Rangaswamy, A., Pingitore, G. M., \& Seldin, D. (2012). The total product design concept and an application to the auto market. Journal of Product Innovation Management, 29(S1), 3-20. https://doi.org/10.1111/j.1540- 
5885.2012.00958.x

Stone, J. \& Rahimifard, S. (2018). Resilience in agri-food supply chains: a critical analysis of the literature and synthesis of a novel framework. Supply Chain Management: An International Journal, 23 (3), 207-238

Tortorella, G. L., Giglio, R., \& van Dun, D. H. (2019). Industry 4.0 adoption as a moderator of the impact of lean production practices on operational performance improvement. International Journal of Operations \& Production Management. https://doi.org/10.1108/ijopm-01-2019-0005

Traill, B. W., \& Meulenberg, M. (2002). Innovation in the food industry. Agribusiness, 18(1), 1-21. https://doi.org/10.1002/agr.10002

Triguero, A., Córcoles, D., \& Cuerva, M. C. (2013). Differences in Innovation Between Food and Manufacturing Firms: An Analysis of Persistence. Agribusiness, 29(3), 273-292. https://doi.org/10.1002/agr

Trippl, M. (2010). Developing cross-border regional innovation systems: key factors and challenges. Tijdschrift Voor Economische En Sociale Geografie, 101(2), 150-160. https://doi.org/10.1111/j.1467-9663.2009.00522.x

Trivelli, L., Apicella, A., Chiarello, F., Rana, R., Fantoni, G., \& Tarabella, A. (2019). From precision agriculture to Industry 4.0 Unveiling technological connections in the agrifood sector. https://doi.org/10.1108/BFJ-11-2018-0747

Voss, C. (2010). Case Research in Operations Management. In C. Karlsson (Ed.), Researching Operations Management (pp. 162-195). New York: Routledge Taylor \& Francis Group.

$\mathrm{Xu}$, L. Da, Xu, E. L., \& Li, L. (2018). Industry 4.0: state of the art and future trends. International Journal of Production Research, 56(8), 2941-2962. https://doi.org/10.1080/00207543.2018.1444806

Zambon, I., Cecchini, M., Egidi, G., Saporito, M. G., \& Colantoni, A. (2019). Revolution 4.0: Industry vs. agriculture in a future development for SMEs. Processes, 36, 1-16. https://doi.org/10.3390/pr7010036 


\section{Appendix A. Interview guide}

\section{Strategy and organization}

Description of the facilities and processes you perform at the company

What kind of customers do your products target? Which dimensions of the products are the most valued by your customers?

What is the relationship like with your suppliers? What product information do you collect from suppliers?

What are the key aspects in managing your company's production? How do you describe the main aspects of the production organization? What are the main objectives for production management?

\section{Industry 4.0 and implementation}

What I4.0 technologies are in place?

What level of integration does the data and equipment have?

How the development and implementation has been done? With own resources? Which external resources have used?

What reasons have led to the implementation of I4.0 technologies?

\section{Product and process innovation}

What has been the process followed for the introduction of I4.0?

Is this the process normally followed for process innovation in your company?

Which been the main players the innovation? What has been the role of the company's management in the process?

How is I4.0 technologies influencing products? New dimensions? 